\title{
THE EFFECTS OF IMPLANTING ADULT HYPOPHYSES INTO SEXUALLY IMMATURE FUNDULUS
}

\author{
SAMUEL A. MATTHEWS \\ (From the Thompson Biological Laboratory, Williams College and the \\ Marine Biological Laboratory, Woods Hole, Mass. ${ }^{1}$ )
}

The factors which control the sex cycle of vertebrates are becoming increasingly clear as a result of numerous investigations. There is gratifying agreement, among all workers on animals above fishes in the evolutionary scale, that the pituitary gland plays a dominant rôle in the direct control of periodic changes that occur in the gonads and associated sexual organs. Control of the sexual cycle in fishes, however, is little understood. Efforts to determine the rôle which the pituitary gland may play in controlling this cycle have yielded conflicting results, particularly with reference to the effect of injecting mammalian pituitary extracts or pituitary-like preparations. Thus Calvet (1932) and Damas (1933) succeeded in stimulating the ovaries of lampreys with prolan and extracts of the mammalian pituitary gland; Boucher, Boucher and Fontaine (1934) obtained an enlargement of the gonads of both sexes in eels which were injected with pregnancy urine and saw evidence of maturation of sperm in the testis; and Morosowa (1936) found that when either pregnancy urine or prolan was injected into perch, laying of eggs and ejaculation of sperm could be produced at any time during the winter. On the contrary Koch and Scheuring (1936) using prolan, Matthews (1939) with injections of sheep pituitary extract and Johnson and Riddle (1939) employing three different mammalian extracts, all of which were shown to be active in stimulating the gonads of birds and mammals, obtained no such effect when these materials were injected into fishes. Fairly uniform results have been obtained, however, by injecting fish pituitary preparations into other fishes. Houssay (1930, 1931), Cardoso (1934), Pereira and Cardoso (1934), von Ihering (1935), and Azevedo, Dias and Vieira (1938) have all observed that the injection of saline suspensions or extracts of fish pituitary glands into other fishes resulted in an enlargement of the gonads and frequently in expulsion of eggs and sperm as well. In the work of von Ihering and of Azevedo, Dias and Vieira mating activities were also elicited in this way. More recently

${ }^{1}$ Aided by a grant from the Williams $1900 \mathrm{~F}$ und. 
Hasler, Meyer, and Field (1939) found that when pituitary extracts of carp were injected into trout, mature eggs and sperm were produced six to seven weeks before the normal breeding season. Further evidence that the pituitary gland may be of importance in controlling changes in the gonads of fishes has been obtained by removing the gland. Vivien $(1938,1939)$ found that after removal of the hypophysis from Gobius marked regressive changes occurred in both testis and ovary; and Matthews (1939) showed that when male Fundulus were hypophysectomized and kept until the next breeding season the testes did not enlarge and become active as did those of control animals, and that no sperm and very little spermatogenic activity were present in the operated animals.

Work so far carried out on fishes, then, indicates that the fish pituitary gland contains some material capable of modifying the normal sex cycle, and suggests that in these forms, as in other vertebrates, the hypophysis is of importance in controlling changes in the gonads and associated organs. If this be true, then the injection of teleost pituitary extracts or the implantation of fresh preparations might be expected to produce an effect on the gonads of sexually immature animals, stimulating them to develop earlier than they normally would. The following is a report of experiments carried out on sexually immature individuals of Fundulus to determine whether or not precocious development of the gonads could be produced in this way.

An adequate supply of small Fundulus was collected in the small salt water streams on Penzance Point, at Woods Hole, by means of a small trap. A number from each group collected were killed immediately and their gonads examined. Of 136 animals examined in this way, ranging in length from 22 to $40 \mathrm{~mm}$. from the tip of the snout to the base of the caudal fin, only 4 of the 65 males (lengths 32 , 34,39 and $40 \mathrm{~mm}$.) showed whitish, active testes with sperm in fresh smear preparations, characteristics of the adult male during the breeding season. The remaining 61 males had testes that were definitely inactive. All 71 of the young females showed only small ovaries with no large follicles. Obviously the vast majority of these small animals were sexually immature

Attempts were made to stimulate the gonads of these immature animals in two ways. In the first series of experiments the pituitary gland of a sexually mature Fundulus was implanted into the eye of an immature animal. From the success achieved with this method in mammals it was hoped that the transplanted gland would maintain itself and provide a continuous supply of any hormones produced by it to the host. From July 25th to August 5th 95 such implants were 
made. The animals were kept in tanks provided with running sea water and a number of untreated young animals were placed in adjacent tanks for controls. Both groups were fed two or three times a week with fresh clam meat. Three experimental animals with controls of the same lengths were killed, two four weeks after implantation of the adult hypophysis and one five weeks following this operation. Of two experimental females only one showed a marked enlargement of the ovary over those of the controls, but microscopic sections showed that in both animals the ovarian follicles and their contained eggs were much larger than those of the control ovaries and that they were provided with larger amounts of vesicular yolk. The testis of the implanted male was also large, was whitish in color, and showed many sperm both in fresh smears and in microscopic sections; while that of the control male, like that found in the majority of untreated males of this size, was small, practically colorless and showed no sperm. The implanted pituitaries were recovered from the male and from one of the females. Sections of them showed fairly normal cells. In only one of them (that of the male) could blood vessels be traced from the tissues of the eye to the implanted gland.

The remaining animals were lost in an attempt to transport them from Woods Hole to Williamstown at the end of the summer.

The following summer a second series of the same sort was run. During the last week in July implants of adult hypophyses were made into the right eyes of 185 young animals, with 112 others serving as controls. For some undetermined reason there was a high mortality in this series. Only 12 males and 12 females of the experimental animals and 38 males and 37 females of the controls were still alive during the first week in September when they were killed and examined. In the females no effect of the implants on the ovary was observed in any case. Of the experimental males only 1 animal, 32 $\mathrm{mm}$. in length, showed an active testis. The implanted pituitary glands were recovered from a number of these animals. Differences between them and the glands recovered from the previous series, where a certain amount of stimulation of the gonads had apparently occurred, were not striking, although in this latter series the cells were somewhat more shrunken and fewer granules were present in the cytoplasm.

Thus of the 27 young animals examined after implanting an adult pituitary gland into the eye, increased activity of the gonads over those of controls was apparent in only four. Since untreated animals of this size occasionally show similar development of the gonads (as in the four males with active testes mentioned earlier), it was certainly not 
clear that the observed increase in activity of the gonads of these 4 experimental animals had been produced as a result of the implantation of the adult gland. In fact, the failure of the other 23 cases to show any effects suggested rather that the implanted glands lacked effective sex-stimulating hormones. It was possible, however, that the transplanted glands did not establish themselves successfully in the eye and that as a result such hormones as they might normally produce were delivered to the circulation for too short a time to be effective. In order to determine which of these possibilities was correct a second method of implanting the adult gland was employed. Preliminary experiments showed that when the pituitary gland of an adult was placed in the peritoneal cavity of a sexually immature animal through a small slit in the body wall the gland could be recovered in an apparently normal condition four or five days later. Twenty-seven young animals were treated in this way. Since the sex of the young animals could not be distinguished, no attempt was made to select the sex of the donors. As in the previous series the experimental animals and controls of appropriate sizes were kept in running sea water in adjacent tanks, both being fed twice a week with fresh clam meat. At three-day intervals each of the experimental animals received a fresh pituitary gland from an adult animal. Such serial implants should provide the immature animal with a fairly constant supply of whatever hormones might be liberated by the adult gland. These animals withstood the handling necessitated by the operations very well. The series was begun on August 8th and ran until September $3 \mathrm{rd}$, during which time only three of the experimental animals died. Records were thus obtained on 24 animals, 10 females and 14 males. In every case the gonads of the experimental animals were much larger and more mature than those of the controls. The females showed not only an increase in size of the whole ovary (Fig. 1) but a marked increase in size and maturity of the eggs (Figs. 2 and 3). The effects on the males were even more marked. The testes of all experimental animals were white and very active, with a high degree of spermatogenic activity as shown in microscopic sections (Figs. 4, 5 and 6). Moreover, in these experimental males the dorsal fin had a prominent black pigment spot which several workers (Newman, 1908; Chidester, 1917; Parker and Brower, 1935) have shown is associated with sexual activity in adult males (Fig. 7).

From these experiments it is clear that when pituitary glands of sexually mature Fundulus are implanted into an immature animal in such a way as to provide a continuous supply of fresh gland material, pronounced stimulation of the gonads of both sexes is produced. The 
evidence obtained from these experiments coupled with that previously obtained by removing the gland in adult males indicates that the pituitary gland of Fundulus, like that of vertebrates above fishes in the evolutionary scale, contains a sex-stimulating substance, presumably a hormone, which is of importance in controlling the development and subsequent seasonal changes in the gonad of this teleost.
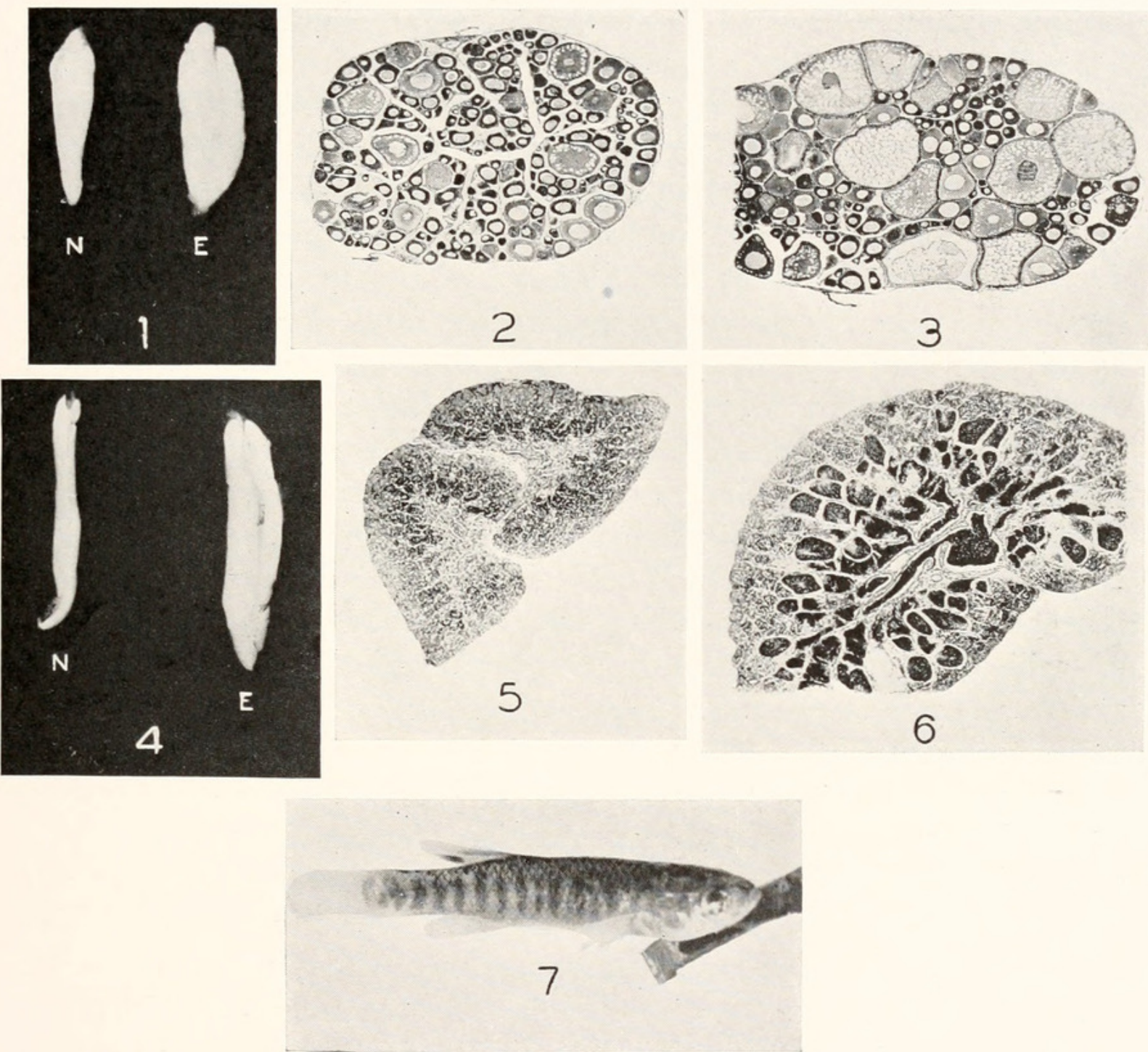

Fig. 1. Ovaries of young Fundulus, $\times 2.5$. N, ovary of normal animal, $32 \mathrm{~mm}$. long; $E$, ovary of female of same length which had received six adult pituitary glands over a period of 26 days.

FIG. 2. Cross-section of normal ovary shown in Fig. $1, \times 25$.

FIg. 3. Cross-section of experimental ovary shown in Fig. 1, $\times 25$.

FIg. 4. Testes of young Fundulus, $\times 2.5$. N, testis of normal animal, $37 \mathrm{~mm}$. long; $E$, testis of male of same length which had received six adult pituitary glands over a period of 26 days.

FIG. 5. Cross-section of normal testis shown in Fig. $4, \times 45$.

FIG. 6. Cross-section of experimental testis shown in Fig. $4, \times 45$.

FIG. 7. Experimental male, $23 \mathrm{~mm}$. long, in which the testis had been activated by implanting adult pituitary glands. Note pigment spot on dorsal fin. 
That this is true of other teleosts as well is indicated by the work on other forms already reviewed. The evidence is quite clear that the teleost pituitary gland, when suitably injected or implanted, will stimulate activity in the gonads of other fishes. While the evidence obtained from injecting mammalian pituitary preparations is not as clear because of conflicting results, certainly most of the recent work shows that such mammalian preparations are either relatively or completely ineffective in producing gonadal stimulation in fishes. These facts suggest that a certain degree of zoölogical specificity of the pituitary hormones may exist, a point of view which has recently been discussed at some length by Creaser and Gorbman (1939). In this connection it is of interest to note that mammalian sexual hormones of both sexes, unlike mammalian pituitary preparations, have produced quite consistent results. Thus Fleischman and Kann (1932) showed that the injection of progynon into adult Rhodeus during the inactive period of the sexual cycle led to development of the oviduct comparable to that found during the breeding season; Berkowitz (1937, 1938) also showed that the feeding of progynon tablets to Lebistes, beginning at birth, caused a suppression of male secondary sexual characters and a marked suppression of spermatogenic activity, without, however, producing any effect on the secondary sexual characters of the female; and Eversole (1939) showed that the injection of testosterone propionate into Lebistes suppressed both body growth and ovogenesis in the female and induced the development of some male secondary sexual characters; while Regnier (1939) caused male secondary sexual characters to appear in females of both Lebistes and Xiphophorus and produced degenerative changes in the ovary by injecting testosterone propionate or merely by adding it to the water of the aquarium in which the animals were kept. Whatever factors are responsible for the lack of response met with when mammalian pituitary preparations were applied to fishes apparently do not apply to mammalian estrogenic and androgenic substances.

\section{SUMMARY}

Pituitary glands of adult Fundulus were implanted into the eyes of sexually immature animals. Of twenty-seven cases examined several weeks after operation the gonads of only four showed greater activity than did those of control animals.

In another series of experiments adult pituitary glands were implanted at three-day intervals into the peritoneal cavity of immature Fundulus. At the end of four weeks all twenty-four experimental animals of both sexes showed a high degree of gonadal stimulation. 
This was particularly notable in the males where large numbers of mature spermatozoa and pigmentation characteristic of the adult during the breeding season were produced. The success of this method of implantation, which continuously supplied the young individual with fresh gland material, indicates that the failure in most cases of the method employing intra-ocular implants was due to a failure of the implanted gland to establish itself successfully so that it provided an inadequate supply of gonad-stimulating substances to the host.

The precocious development of the gonads produced by implanting the adult pituitary gland strongly suggests that the normal development of the mature condition of the gonad in Fundulus is controlled by the pituitary gland.

\section{LITERATURE CITED}

de Azevedo, P., M. V. Dias, E B. B. Vieira, 1938. Biologia do saguirú. Mem. Inst. Oswaldo Cruz., 33: 481-554.

Berkowitz, P., 1937. Effect of estrogenic substances in Lebistes reticulatus (guppy). Proc. Soc. Exp. Biol. Med., 36: 416-418.

-, 1938 . The effects of estrogenic substances in Lebistes reticulatus (guppy). Anat. Rec., 71: 161-175.

Boucher, S., M. Boucher, and M. Fontaine, 1934. Sur la maturation provoquée des organes génitaux de l'anguille. Comft. Rend. Soc. Biol., 116: 12841286.

Calvet, J., 1932. Action du lobe antérieur d'hypophyse chez divers vertébrés (Lamproies, oiseaux). Compt. Rend. Soc. Biol., 109: 595-597.

Cardoso, D. M., 1934. Relations entre l'hypophyse et les organes sexuels chez les poissons. Compt. Rend. Soc. Biol., 115: 1347-1349.

Chidester, F. E., 1917. Hermaphroditism in Fundulus heteroclitus. Anat. Rec., 12: $389-396$.

Creaser, C. W., and A. Gorbman, 1939. Species specificity of the gonadotropic factors in vertebrates. Quart. Rev. Biol., 14:311-331.

Damas, H., 1933. Note sur l'apparition naturelle et provoquée des caractères sexuels chez la Lamproie. Bull. Soc. Roy. des Sci. de Liège, No. 4, pp. 94-98.

Eversole, W. J., 1939. The effects of androgens upon the fish (Lebistes reticulatus). Endocrin., 25:328-330.

Fleischmann, W., und S. Kann, 1932. Über eine Funktion des weiblichen Sexualhormons bei Fischen. Arch. ges. Physiol., 230: 662-667.

Hasler, A., R. K. Meyer, ANd H. M. Field, 1939. Spawning induced prematurely in trout with the aid of pituitary glands of the carp. Endocrin., 25: 978983.

Houssay, B. A., 1930. Accion sexual de la hipofisis en los peces y reptiles. Rev. Soc. Argentina Biol., 6: 686.

1931. Action sexuelle de l'hypophyse sur les poissons et les reptiles. Compt. Rend. Soc. Biol., 106: 377-378.

von Ihering, R., 1935. Die Wirkung von Hypophyseninjektion auf den Laichakt von Fischen. Zool. Anz., 111: 273-279.

Johnson, M. W., AND O. RiddLE, 1939. Tests of mammalian gonad-stimulating hormones on gonads of fishes. Proc. Soc. Exp. Biol. Med., 42: 260-262.

Koch, W., und L. Scheuring, 1936. Die Wirkung von Hypophysenvorderlappenhormon auf den Laichakt von Fischen. Zool. Anz., 116: 62-64. 
Matthews, S. A., 1939. The relationship between the pituitary gland and the gonads in Fundulus. Biol. Bull., 76: 241-250.

Morosowa, T. E., 1936. Die Wirkung des Prolans und des unsterilisierten Harns schwangerer auf die Reifung der Geschlechtsprodukte des Barsches. Zool. J. Moskau, 15: 169-174.

Newman, H. H., 1908. A significant case of hermaphroditism in fish. Biol. Bull., 15: $207-214$.

Parker, G. H., and H. P. Brower, 1935. A nuptial secondary sex-character in Fundulus heteroclitus. Biol. Bull., 68:4-6.

Pereira, J., Et D. M. Cardoso, 1934. Hypophyse et ovulation chez les poissons. Compt. Rend. Soc. Biol., 116: 1133-1134.

Regnier, M., 1939. Action du propionate de testostérone sur les gonades de quelques Cyprinodontes vivipares. Compt. Rend. Acad. Sci., 208: 2109-2110.

Vivien, J., 1938. Sur les effets de l'hypophysectomie chez un Téléostéen marin, Gobius paganellus L. Compt. Rend. Acad. Sci., 207: 1452-1455.

1939. Rôle de l'hypophyse dans le déterminisme du cycle génital femelle d'un Téléostéen, Gobius paganellus L. Compt. Rend. Acad. Sci., 208: 948-949. 


\section{$2 \mathrm{BHL}$ Biodiversity Heritage Library}

Matthews, Samuel A. 1940. "THE EFFECTS OF IMPLANTING ADULT HYPOPHYSES INTO SEXUALLY IMMATURE FUNDULUS." The Biological bulletin 79, 207-214. https://doi.org/10.2307/1537840.

View This Item Online: https://www.biodiversitylibrary.org/item/17195

DOI: https://doi.org/10.2307/1537840

Permalink: https://www.biodiversitylibrary.org/partpdf/27128

\section{Holding Institution}

MBLWHOI Library

\section{Sponsored by}

MBLWHOI Library

\section{Copyright \& Reuse}

Copyright Status: In copyright. Digitized with the permission of the rights holder.

License: http://creativecommons.org/licenses/by-nc-sa/3.0/

Rights: https://biodiversitylibrary.org/permissions

This document was created from content at the Biodiversity Heritage Library, the world's largest open access digital library for biodiversity literature and archives. Visit BHL at https://www.biodiversitylibrary.org. 